\title{
Conceptualizing Framework for Women Empowerment in Indonesia: Integrating the Role of Media, Interpersonal Communication, Cosmopolite, Extension Agent and Culture as Predictors Variables
}

\author{
Che Su Mustaffa ${ }^{1} \&$ Fauziah Asyiek ${ }^{1}$ \\ ${ }^{1}$ School of Multimedia Technology and Communication, College of Arts and Sciences, Universiti Utara \\ Malaysia, Sintok, Kedah, Malaysia \\ Correspondence: Che Su Mustaffa, School of Multimedia Technology and Communication, College of Arts and \\ Sciences, Universiti Utara Malaysia, 06,010 Sintok, Kedah, Malaysia. E-mail: chesu402@uum.edu.my
}

Received: February 24, 2015 Accepted: May 14, 2015 Online Published: June 13, 2015

doi:10.5539/ass.v11n16p225 URL: http://dx.doi.org/10.5539/ass.v11n16p225

\begin{abstract}
Over the last several decades, considerable efforts have been made by the Indonesian government to provide women farmers and women on the farm with efficient, effective, and appropriate technology, training and information. The positive effects are beginning to show in agricultural production statistics and indices of family welfare fall short of what is needed at a time when public sector investments in agricultural research and extension are under pressure, when ever-greater demands are being placed on rural women in the face of rapid social transformation, and in an increasing number of areas, when evidence of environment degradation is mounting. Thus, this paper discusses the role of social system, organization support, communication behavior (cosmopolitan, interpersonal communication, media) and agents of change, and proposed a conceptual framework for future study. Based on the explanation given, this paper therefore focuses on the aspects of communication behavior and empowerment of women farmers that are related to some variables which are the characteristics of women farmers, social system, the availability of supporting organizations for agricultural business and the performance of the empowerment of womenfarmers in agribusiness regarding their ability to make decisions and psychological empowerment in agricultural business.
\end{abstract}

Keywords: women empowerment, communication behavior, organization support, competency, social system

\section{Introduction}

In meeting the needs of life and in surviving in life, human beings need to interact with their surroundings through social relationships and communication (Soekanto, 2006). Communication is an important factor that contributes to the existence of social interactions that lead to the process of transferring information, ideas, attitude or emotions from one individual to the other. This situation can occur directly or through the use of communication media (Gerbner, 1967; Theodornoson \& Theodornoson, 1969; Effendi, 2002). According to Rogers and Kincaid (1981), communication is a process involving two or more individuals who create and transfer information to each other with an order that is usually meaningful. Tubbs and Moss (2000) in their study discovered that $83 \%$ of human beings used their time for communication.

Communication behavior involves an activity where an individual provides opportunities for them to search for and receive information via the existing communication channels. According to Rogers (1983), individual or collective communication behavior can be seen when there is participation, a relationship with the social system, cosmopolitanism, relationship with the agents of change, exposure to the mass media, active information searching, knowledge on current issues (innovation) and leadership. Communication behavior can be related to the empowerment of a community.

Changes are expected to happen from empowerment programs. Conventional society is expected to change into a more dynamic community that actively gets involved in and being independent in discovering the existing potential in the community itself. Besides, empowerment programs focus mainly on the country society in an attempt to expand agricultural business system via the agents of agriculture expansion (Saragih, 2000; Suparta, 2001).

The empowerment of society is for the objective of changing individuals or the society into being independent. 
This can be seen from the ability to think, make decisions, and do something appropriately for the purpose solving a problem with cognitive, affective, and cognitive and psychomotoric abilities (Hikmat, 2004; Sidu, 2006; Haryanto, 2006).

Therefore, the empowerment of society should involve males and females. This can be implemented through developmental programs with a gender vision or prospectively gendered development (The Office of the Country's Ministry of Female Empowerment, 2008). Thus, farmers including the female ones living in country sides as a farming community are encouraged to participate in the agricultural development programs.

\section{Problem Statement}

Indonesia is an agrarian country with $60 \%$ of its citizens living in country sides and earning a living mainly in the field of agriculture (Syamsuri, 2010). On the other hand, $49.1 \%$ of Indonesian residents are women and 25\% of them are the heads of their family. A majority of these people are the needy (The Office of the Country's Ministry of Female Empowerment, 2007). In addition to that, a majority of the poor people (63.15\%) live in the rural areas (Mulyana \& Surono, 2010). Besides, women farmers in the rural areas have contributed so much to the development of agricultural activities in supporting their family financially (Haryani, 2004; Ipriani, 2005).

The development paradigm proposes the principles of seeing women as equally contributive as men towards development and more importantly of practicing gender equality and equity. Women are not only the objects of development, but also the subjects and the pioneers of the success of development. This can be realized with a developmental concept that focuses on gender equality and equity or gender mainstreaming. This concept can promise equal opportunities in the involvement of women and men in planning, implementing, evaluating and decision making in development programs (Kantor MenUPW, 2000).

In Indonesia, generally women farmers in the country society do not only play their role in the completion of house chores (domestic), but also in economic activities (productive) and social relations (Vitalaya, 2000). However, such a role is not always played collaboratively in a positive way in family's decision-making neither regarding domestic activities nor productive (economy) as well as social ones. Some studies revealed that women's use of time in productivity was more than men even though men were more dominant in decision-making in the aspect of productive activities. In the profile of access and control in some aspects of decision-making, women are more subordinate (Wulansari, 2001; Munaf, 2004). This situation indicates how strong social values in the culture of the country society are in some local areas (Sayogyo, 1983; Pical, 1997, Wariso, 1999).

Agribusiness is a new idea for women farmers in the rural areas as such field has been dominated by men all this while even though women have contributed a lot in agricultural activities (Wahyuni, 2003; Ipriani, 2005; Mannopo, 2009; Mehra \& Rojas, 2008).

The women in Indonesia are still lacking in receiving and searching for information. This is because women farmers have not yet fully involved in the agricultural expansion activities (Herawati, 2000; Marliati, 2008; Mardikanto, 2007). In fact, empowerment process is closely related to communication and the adoption of innovation. The empowerment of female farmers and communication activities are inseparable in receiving and searching for information from various information resources for the purpose of developing their agricultural activities including their activities in the agricultural expansion program as well as in facing the pressure of the existing social system. According to Bennis et al. (1969), the two blocking factors for changes are individual obstacles (individual characteristics) and social system obstacles (norms/custom and the attitude of people in the close community). The role of informal leadership or opinion giving and charismaticsm in receiving a change is so great in altering the attitude of the people in the society (Rogers, 1995; Schoorl, 1995).

Lailogo's (2003) study revealed communication behavior of women farmers was still moderate yet cosmopolitan enough, even though they had lack of exposure to the mass media. Based on Oktarina's et al. (2009) research in the South Sumatera, the knowledge of female farmers in faming activities was still intermediate. The involvement of women in the activities of information searching from the mass media and collective communication were still in the moderate category. This means the women farmers' empowerment should be improved through identifying the contributing factors towards empowerment which are the women's internal factors and external factors that can be the reasons for transforming the women towards being independent in decision-making in agricultural activities in the agribusiness system. Besides, the availability of sources of information or training is important in the contribution and participation of women farmers in agriculture and the development of country society. Even though the role of women in development is being paid more and more attention, the issues of communication in relation to gender in the agriculture context are rarely discussed. 


\section{The Empowerment of Women Farmers}

Empowerment refers to how an individual, a group or a community controls their own lives for the future of their own choice (Shardlow, 1998). According to Narayan (2002), empowerment involves growing assets and increasing the ability to participate in negotiating by influencing, controlling and managing the institution responsible and influential to their lives. On the other hand, Slamet (2003) claims that empowerment refers to the efforts involved in making the society understand, comprehend, motivated, able to see opportunities, make use of opportunities, synergic, able to cooperate, know the different varieties of alternatives, manage to seek for information and able to act according to situation. The existence of empowerment can be seen in the ability to be independent, to make decisions and to stay out of pressure.

According to Hill and Holmbeck (as cited in Laman et al., 1998), independence is of two aspects: interpersonal and psychology. Interpersonal aspect refers to the relationship between an individual and another individual, while psychological aspect is related to the relationship between an individual and himself/herself. Zimmerman (1995) believes that psychological empowerment can be of three dimensions which are attitude (attitude of control and competence), appearance and knowledge, and participatory behavior.

Empowerment through agricultural business activities can improve one's independence and participation and the ability to make decisions in the sub system of providing production means, production, alteration and marketing of agricultural products (Haryani, 2004; Marliati, 2008).

Empowerment basically is an approach towards identifying the existence of power not only in the form of domination of one individual to the other. The approach is more towards discovering the women's capacity in improving their independence and inner strength (Mosse, 1996).

According to Slamet (2003) the level of independence of women depends on the quality of the women's own source of strength. Even though the women farmers who live in the rural areas where modern civilization is out of reach and who are always considered poor, basically they do have the potential, capability, need and wish to succeed in life. Dismodernism, lack of intellectuality and poverty are not constantly and eternally embracing the women farmers. Despite their low ability, they still have the potential to succeed when there are empowerment activities for the purpose of discovering their potential. The womenfarmers also have their own needs and desires that can be fulfilled themselves when their potential and ability are developed (Slamet, 2003; Haryani, 2004).

However, the social system in Indonesian society still practicing patriarchy. This situation also happens in developing countries. According to Wood (1997), patriarchy concept mirrors experience, values and the importance of men as a powerful group that protects their privileges but simultaneously rejects and ignores the rights of women. This situation can be related to the level of participation and independence of women farmers. Even though there are a lot of empowerment programs conducted in the rural areas, the involvement and independence of women are still moderate (Meneg Office PP, 2009). According to Sulistiyani (2005), the empowerment of the society aims at shaping individuals and the society to be independent. Being independent can be seen in the way they think, act and deal with things.

The existence of independence in the society can be observed in the existence of the ability to think, make decisions and do things that are considered perfect in solving problems using the strength and ability possessed. Independence comprises some aspects: 1) material independence (productive ability in meeting material needs), 2) intellectual independence (ability and strength control), 3) attituditional independence (self-awareness, initiative, motivation, self-belief, decision-making for actions, and 4) managerial independence (the ability to build, implement and organize collective activities), all for the purpose of making changes in the farmers' lives. Steinberg (2001) argues that the dimensions of independence among others are related to behavioral independence where an individual is able to make his/her own decision and implement that decision. Behavioral independence is one dimension of independence that involves the function of an independent individual who is active and has freedom in action (Sprinthaal \& Collins, 1995). Mosse (2007) claims that empowerment approach aims at shaping women towards being independent and having internal strength.

Saleh's (2006) research indicated that there was an obvious relationship between personal characteristics and direct communication. Rascide and Walker (2001) believe that innovative information and knowledge are the main yardsticks in determining the success and failure of agribusiness. Therefore, the women's access to innovative information and knowledge is important for the development of the role of women farmers in the country society today. Besides, the availability of channels for obtaining information or training are crucial in influencing the contribution and participation of women farmers in agriculture and the development of country society. 
In the context of communication development, identifying the communication behavior of the women farmers is significant in improving the agricultural development program for the empowerment of women farmers in the rural areas. Therefore, the empowerment of women farmers in increasing their communicative participation should first identify the communication behavior of the women. Upon doing so, a perfect picture of the pattern of communication behavior between a farming couple or inside the house of farmers and even their social relationships can be obtained. This is very useful in planning the strategy for agricultural development in transferring information, knowledge and technology in the agricultural development programs, empowerment of women as part of agricultural activities and as ones who play an important role together besides their husband.

Based on the explanation given, this paper therefore focuses on the aspects of communication behavior and empowerment of women farmers that are related to some variables which are the characteristics of women farers, social system, the availability of supporting organizations for agricultural business and the performance of the empowerment of female farmers in agribusiness regarding their ability to make decisions and psychological empowerment in agricultural business.

\section{Personal Characteristics of Women}

Bettinghaus (1983) claims that there are some social economic characteristics that can determine communication behavior and innovation adoption that is more comprehensive. Among demographic characteristics are age, education and income. Rogers and Shoemaker (1995) divide the characteristics of innovation receiver into three dimensions: social economic, individual and communicative characteristics.

According to Lionberger and Gwin (1982), the characteristics of individual farmers that are related to every aspect of life and surroundings are age, education and psychology (rationality, flexibility, and mentality, orientation of agriculture for business and innovation acceptance). Slamet (1992) suggests that the factors that influence the process of diffusion innovation are age, education, social economic status, relationship patterns and attitude.

Information plays an important role in shaping the visionary thinking of farmers on the reality they are facing. Some information received by the farmers can change the concepts held strong within them which in turn will be internalized in their way of thinking that consequently will form a new concept that is the result of the suiting the old information with the new one. The more information received, the more dissatisfaction experienced with the current condition which leads to implementation of changes to meet the unfulfilled needs of the farmers. Such demand has influenced the farmers to search for new ideas in their agricultural activities which finally will make the farmers become more dynamic. As mentioned by Kaye (1997), to identify the actual main problem being faced by an individual, he/she should get a lot of information. The activities or behavior in searching for information needed by someone depends on the characteristics of the sources of information and the quality as well as intensity of interaction between the farmers and the information sources. Besides, individual characteristics are one of the most important factors in investigating how the farmers can benefit from the sources of information.

Individual characteristics are the characteristics of someone related to all aspects of life the others concerned. Individual characteristics basically are personal. They exist as a result of biological and sociofisycology factors. Biological factors include genes, nervous system and hormone system. According to Sampson and Rakhmat (2005), sociopsychology factors consist of cognitive components that are related to cognitive aspects (intellectual) that involve what is known to human beings and what concerns the normality, and affective aspect that involves feelings (emotion).

Demographic factors are one of the variables that are often utilized to investigate an individual's communication ability and the choice of communication media. According to Lionberger and Gwin (1982), individual characteristics are an individual's personal aspect that includes age, educational level and psychological characteristics. Therefore, individual characteristics are the factors that should be considered in order to identify an individual's behavior including his/her communication behavior and all other behaviors in life such as agricultural one especially in agricultural business system. Based on the study conducted by Wardhani (1994), demographic characteristics were related to the sources of information. The demographic factors are important in communication behavior and can be utilized for the purpose of developing a business.

Besides, Marliati (2008) discovered that the farmers' characteristics, formal education and non-formal education and social system (the facilities provided by the authority concerned for agricultural business and the access to organizations agricultural business) were significant influences in meeting the need for expanding the capacity of the famers in agricultural business in Kabupaten Kampar, Riau. However, the other factors such as age, experience in agricultural business and the width of farming land did not show any significant influence. 
Pambudy (1999) argues that communication behavior of breeders was influenced by the individuals' characteristics such as age, family members, breeding period, education and products. On the other hand, the study of Jokopusphito (2006) indicated that the factors that influenced communication pattern of a group of women farmers were education, farming experience, cosmopolitanism, knowledge on the diversity of food and nutrition, and the status of the members in the group. However, Pertiwi (2009) claimed that when innovative characteristics were seen from the perspective of social status, the width of farming land and the level of risk taking showed an obvious relationship with the farmers' perception in interpersonal communication even though the empathy level, futuristic level and social participation level and the involvement in development were correlated so obviously in the interpersonal channel. Besides, perception towards media channels shows that only social status that correlated obviously with futuristic level. Besides, communication activity level and the involvement in extension agent correlated significantly. Therefore, the width of land showed that it had a negative relationship with media communication channels. According to Saleh's (2006) study, there was an obvious relationship between educational level, economic class and the possession of mass media, and the role of interpersonal communication on the role of communication of group members in the expansion of communication network. However, exposure to the mass media (radio, television, books) did not show any significant relationship. The results of Monoppo's (2009) study revealed that motivation, cosmopolitanism and productive role of women farmers as the internal factors was correlated to the participation of women farmers in the cocoa farming in Kacamatan Palolo, Kabupaten Donggala, a province in the South Sulawesi. However, the other factors such as age, education, farming experience, aspiration, decision-making and the allocation of time for domestic role did not correlate in an obvious way.

A study by Far (2009) shows that individual characteristics such as age, education, income, farming experience, width of land plot are closely related to interpersonal communicative behavior of wetland paddy field owners in Waimital Village, Kairatu District, Western Seram County. The relationship shows that the higher the age, education, income and width of plot ownership possessed by a farmer, the better and more intense his interpersonal communication. Individual characteristics and interpersonal communicative behavior are positively related to farming behavior, that is, between width of a farming plot and knowledge and action to farm, positive relationship between the researcher and knowledge of farming behavior, and positive relationship between farmers and their wetland paddy farming behavior.

Haryani (2004) states that width of plot is closely related to female farmers' independence in choosing types of commodity and marketing. Conversely their perception to group role is slim. Their internal factors among others, educational background, time use, farming experience, perception to farming institutions are not really related to female farmers' independence in choosing vegetable business management in Sukaraja District, Sukabumi County, West Java Province.

Lailogo (2003) reports that women farmers in Amarasi District, Kupang County, NTT fall in the Medium Scale and less expressive in their communication with mass media. However, they are cosmopolite and involve themselves in communicative forums; they interact with outside world, have empathic skills, and facilitate new ideas to come into their social system.

A study by Pambudy (1999) finds that livestock farmers' communicative behavior depends on their individual characteristics such as age, number of dependents, time span, education and incomes. In Pakistan, a male dominated country, participation by female Pakistanis in a decision making process is low. Zapar, Batool, and Bano (2005) maintain that the females of different socio-economic characteristics participate in different degrees in decision making process. Respondents with higher education show strength in decision making process.

Past studies show that a lot of individual characteristics influence the way people accept innovation (Rogers, 1969; Salkind, 1995; Slamet, 1995; Mardikanto, 1993, Bettinghaus, 1983; Roger \& Shoemaker, 1971). However, Roger (1995) stresses the importance of age, formal education, number of dependents, farming experience, family income, cosmopolite, participation, public institution, group involvement, and media relation. Sumardjo (1999) support this; he states that personal characteristics to study are age, education, experience, cosmopolite, skill, perception, gender, motivation, health, and information facility.

\section{Social System}

According to Rogers and Shoemaker (1971), a social structure in a social system functions to inhibit or facilitate diffusion stages and new ideas to permeate in system impressions. Sources of system impressions include norms, social status, hierarchy, and others that influence individuals in the system. Robins (1998) and Lunenberg and Ornstein (2004) state that norms constitute rules or intangible behavior that influence group behavior. A group or organization functioning as a system will create a collective organizational culture and operate on time and group 
system (Pettigrew, 1979). Che Su (1998) an organizational culture consists of beliefs and extended and formed norms that are developed by a group based on experience and accepted as good when group members look at, feel, and evaluate the group. Hoy and Miskel (2005) and Alvesson (2002) define an organizational culture as association of orientation that involves norms, values, philosophy, perspectives, beliefs, views, attitudes, myths, and assumptions shown by organization members though attitudes and behavior (Chang, 2005). Stein (1992) states that an organizational culture is based on two sources namely beliefs, values, and assumptions by founder(s) of the organization, and learning experiences of members when the organization is developing. Shaskin and Kiser (in Hardjosoedarmo, 1996; Tusakdiah, 2010) argue that an organizational culture consists of two components: first, values, things founders of the organization evaluate as right or wrong, and, second, beliefs, ways they consider things to be done in the organization. Therefore, an organizational culture can be defined as values, behavior, beliefs, standards, attitudes and customs that must be realized by members of the organization. In other words, values and beliefs are formulated and expressed by an organizational leader and his/her members.

In relation to village dwellers' association or organization dealing with adopting and diffusing innovation, Rogers and Shoemaker (1971) believe that a social structure in a social system functions to inhibit and facilitate diffusion stages and new ideas to permeate through system effects. Elements of a social system are norms, social status, hierarchy and other aspects that influence individual behavior of its members. Influential power of the elements creates problems whether or not communicative behavior of female members is inhibited in a communicative activity. Female farmers as an integral element of a development organization in villages play a strategic role in increasing a family's status but are limited by skills and opportunity. Such situation is limited by the existing social system, by the surrounding members in a patriarchal system. Female farmers are not only housewives but also income earners because they are involved in an income-generating farming activity but their opportunity is limited. The patriarchal system places rural women a weak position. However, this system varies in different agricultural civilization (Women in Patriarchal Societies, 2011).

Van Den Ban (1960) maintains that traditional and modern norms related to agricultural innovation are influenced by individual characteristics such as education, width of farming plot, and incomes. If the farmers have higher education, wider farming plot, and higher incomes in a city but with traditional norms, they adopt less innovation compared to those with lower education, less farming plot but with modern norms (Rogers \& Shoemaker, 1971). Qodir (1966) did his research in the Philippines; he found that a modern system with open social condition causes individuals to be innovative although they are less educated, and less familiar with mass media. According Rogers (1995) and Schroorl (1980), the role of an informal or charismatic leader in accepting innovation is very much influential in changing the behavior of society members. Rukminto (2001) maintains that designing a behavioral change is hard on the individual and group levels by a society because there is hindrance to such attempt. Manoppo (2009) finds that more women farmers cannot follow up agricultural development, for example, to develop a cocoa business center in Palolo District, Donggal County, South Sulawesi. This system enforces the women farmers to limit themselves for domestic concern and the male for public activity. The female cannot be involved in various development activities such agricultural one, accessing information from mass media, information from their own circle or cosmopolite. What happens to them then is that they have a low agricultural trade system (Haryani, 2004; Marliati, 2008).

Studies in (Bennis et al., 1969; Rogers \& Shoemaker, 1971; Qodir, 1995; Rogers, 1995; Haryani, 2004; Manoppo, 2009) indicate the starting point of a hindrance is in individual characteristic and social system surrounding the society members. In brief, woman empowerment is related to the social system. A problem arises here is whether or not there is a social system, that is, (socio-cultural values, organization culture, local leader), which is related to communicative behavior and farmer empowerment.

\section{Agribusiness Support Organizations}

In an agricultural business system, an agribusiness support organization constitutes a subsystem. This organization is one of information resources for farmers, including female ones in a village. It is governmental or non-governmental. It can be a Balai Penyuluhan Pertanian (agricultural extension agency), financial agency or bank, cooperative, market, research institution, communication and transportation service (Daniel, 2002).

Through this agribusiness support organization, an agricultural trade system in a village is formed and supported by relevant subsystems: (1) procurement and distribution of production means, (2) technology and development of agricultural resources, (3) agro-industrial processing, and (4) marketing. Other subsystems, such as a governmental agency, are the environment for the agricultural trade to grow.

A study by Marliati (2008) shows that empowerment is not fully facilitated by agribusiness support organizations 
such as access to experts, agricultural development institution, and research institutions. Governmental and non-governmental effort is to increase agribusiness facilities in that farmers have easy access to a variety of resources. Balai Informasi Pengembangan Pertanian (BIP)/(Agricultural Development Information Center), a central unit at the sub-district level, should have an autonomy to be more effective and more resources (Badan Agribisnis, 2003).

A study by Tamba (2007) finds that farmers' competence to access information is low. This indicates that farmers rarely interact with farmer groups, agricultural development agents, and innovators. BIP does not play a role in providing information. Another problem is that there exists a lack of cooperation among governmental agencies to increase empowerment, self-sufficiency, farmer welfare. Agricultural development agencies constitute an information resource for the empowerment of farmer groups (Sumardjo, 1999; Slamet, 2003; Marliati, 2008; Anantanyu, 2009).

\section{Performance of Agricultural Development Agencies}

Agricultural development agencies (ADA) are one of information resources for the empowerment of an agricultural society (Sumarjo, 1999; Slamet, 2003; Marliati, 2008; Anantanyu, 2009). Thus, competence or performance of ADA is crucial for agribusiness farmers. ADA's role is to increase their participation, agribusiness organizations, resource access, and strong partnerships among females' business units in making use of technological innovation. In addition to the role mentioned before, Rogers (1983) believes that ADA can influence the adoption of decision making process and innovation; the farmers should have effective use of agricultural development methods in order for farmers to form their own opinions and make their own decisions. Empowerment strategies and models provided by ADA can create farmers' independence in deciding to adopt innovation (Agussabti, 2002).

According to Laswell (1969), a communication process is the one that create new values. It means that communication about development functions as a dissemination of socio-cultural values and new welfare values, be it related to cognitive aspects (knowledge), psychomotor (skills), or affective (attitude, mental). Furthermore, Lionberger and Gwin (1982) argue that an ADA as change agent has the multiple responsibilities for passing the information and changing the behavior of targeted society members. ADA as a communicator should influence female farmers to have certain kind of behavior to be involved in the development process.

Anwar (2007) elaborates that farmer involvement is triggered by structural gaps in a social system. Among others, is the gap of the ability to receive information and opportunity to make use of it? Rascide and Walker (2001) argue that, in business, innovative information and knowledge are two crucial factors that guarantee success or failure. Therefore, access to knowledge and innovative information are important for the females to increase their role in the village agriculture. Channels for obtaining information and training are the means to maintain the females' participation and the village agricultural development. Although they receive more attention in the development process, their communication issues and gender are discussed in the agricultural context.

Quisumbing \& Lauren (2007) and Manoppo (2009) show that the women farmers experience less access to getting information from ADA. Marliati (2008) argues that performance of ADA falls in the FAIR column. This indicates that ADA fails to identify targeted characteristics to pass agricultural information. Anantanyu (2009) finds that steps undertaken by ADA, directly or indirectly, enable the farmers to manage their business better, participate in group activities and increase their skills. In line with this Farid (2008) reports that factors closely related the farmers' independence to make their decision are clearly influenced by information access and ADA.

Asngari (2002) states that ADA should create educational activities to change targeted behavior as planned so that the farmers are more empowered and self-sufficient. Furthermore, Van Den Ban and Hawkins (1999) suggest that ADA should involve farmers to purposefully communicate information in order to help each so that they can make appropriate conclusion. It is seen here that ADA have an important role in connecting the information center and the village farmers. Nuryanto (2008) concludes that determining factors to cause low performance of ADA is the low competence of ADA officers, their cosmopolite, supports by the environment (government policy, organizational structure, technology, facilities, and leadership).

Nuryanto (2008) shows that determining factors to cause ADA's low performance is the competence of the officers, their low cosmopolite, and supports by the environment (government policy, organizational structure, infrastructure, and leadership model). Marliati (2008) reports that ADA officers still perform poorly in empowering the farmers to manage their trade. This condition is caused by lack of agribusiness facilities. In addition, change for innovative behavior is not effective and farmers' participation is less visible. Thus capacity for agribusiness development is not fulfilled. Muliady (2009) finds that performance of ADA officers in 
information management and leadership directly influences the farmers' behavior in Karawang, Sukabumi, and Subang Counties of West Java Province. The study identifies factors that cause the farmers to participate are their agricultural characteristics (formal and nonformal education), socio-cultural characteristics, and access to agribusiness organizations.

However, in contrast to Anantanyu's study (2009), ADA support, directly or indirectly, improve an increase in the farmers' agribusiness capacity, their group participation, and their group competence. Farid (2008) believes that factors influencing the farmers' self-sufficiency are information access and ADA activities.

Therefore, there must be studies on empowerment related to the agribusiness system, performance of ADA, communication behavior and female farmers. Theory and concepts proposed by experts (Laswell, 1969; Rogers, 1983; Lionberger \& Gwin, 1982; Bernandin \& Russell, 1983, Mardikanto, 1993; Slamet, 2003) are relevant for this study. Performance of ADA in empowering female farmers is measured by the following indicators: (1) developing knowledge and communication, (2) helping information access, (3) increasing knowledge in technological innovation, (4) functioning as a facilitator, (5) locating literature as information resources, (6) undertaking field try out (Gupta \& Sundarswamy, 2004).

\section{Communicative Behavior}

Communicative behavior refers to activity of receiving and finding relevant information. An individual's behavior to be involved in a communication activity arises from his desire to act upon his wish (Pambudy, 1999). Following transactional models, communicative behavior is one's action to be a communicator. Communication is seen as a sharing of experience (Tubb \& Moss, 1993; Effendi, 1997; Mulyana, 2007). Rogers (1983) argues that catalysts of communicative behavior include participation in communication, interpersonal communication, and availability of mass media, cosmopolite, change agents, and leadership.

\subsection{Cosmopolite}

Rogers (1995) defines cosmopolite as a person who is open, easily adjustable, friendly, and inquisitive to seek information for his/her job and respond to innovation. Cosmopolity refers to degree of someone's openness for ideas, knowledge, and information from outside of his social system.

Rahman and Naoroze (2007) view cosmopolity of females in Bangladesh in an empowerment project through participation in human relation measured by frequency of visits to friends and relatives, to markets and officials; the indicator before and after the project shows low degree of success. It can be concluded that participation of female farmers in human relation activities has not significantly improved their empowerment after the project was completed.

Tarmali (1994) shows that cosmopolity of farmers' correlates with the application of Supra Insus. It also applied to Abdurrahman's study (1998). The study concludes that cosmopolity of farmers' correlates with acceptance of PHT. Cosmopolity of a person can be measured by (1) number of visits to information resources for innovation, (2) frequency of contacts to people outside his/her group, (3) distance from home to information resource, (4) time spent for TV and radio, and (5) frequency of reading newspaper

Lailogo (2003) finds that communicative behavior of women farmers is cosmopolite enough. This means that women farmers also seek information from outside of their village; they apply the innovative technique to improve the cows' weight. This is in contrast to Manoppo's study (2009). Female coca farmers in Palolo District, Central Sulawesi, are less cosmopolite; $55.5 \%$ of them score below 9.67 . They rarely visit information centers in and outside their village, make use of mass media to seek information for cocoa farming. Jokopuspito (2006) states that one of the factors influencing communication patters of female farmers are cosmopolity. Subagio (2008) adds that education and cosmopolity are distinctive individual characteristics that empower and develop farmers' competence. Farid (2008) support this. Cosmopolity of vegetable farmers in Pasuruan and Bondowoso is very low. Thus, cosmopolity affects the farmers' capacity.

\subsection{Mass Media}

Mulyana (2007) defines mass communication as the kind of communication that uses mass media, in the form of print (newspapers, magazines, bulletins), and electronic (radio, television) addressed to a large number of audience or people and heterogeneous in nature. A study on an electrical save-energy campaign for housewives in Depok is reported by Wiryanta (2009). He finds that there is no relationship between availability of mass media and electrical save-energy behavior although the housewives receive written mass media more frequently. However, there is a correlation between availability of mass media and interpersonal communication, and the housewives' electrical save-energy behavior. He suggests that the effect of mass media works slowly through interpersonal communication. 
Hapsari (2007) finds that mass media (print and electronic) is not used as sources of information for finding information about food and nutrition but as media for entertainment. Sally et al. (2009) states that female farmer communicative activities related to availability of mass media fall in the scale of medium. Most farmers, including the female ones use mass media as entertainment, not as means for improving their agricultural activities (Hayati, 2008; Lailogo, 2003; Hapsari, 2007; Hadiyanto, 2001; Pambudy, 1999).

\subsection{Interpersonal Communication}

De Vito (1989) in his book "The Interpersonal Communication Book" defines interpersonal communication as process of sending and receiving messages between two persons or among a grouns people with some impressions and some immediate feedback. Compared to other forms of communication, this type is effective in changing attitudes, beliefs, views and behavior of communicators. It is effective because the communication occurs face to face. Thus, the personal relation enables the communicators to identify reactions and provide immediate feedback. Feedback is directly seen in the expressions shown by the communicators, positive or negative. Finding negative feedback, a communicator may change his way of communicating to make it a success. Rogers (2003) maintains that a person may adopt innovation if he communicates personally as a change agent or a public figure.

Tjiptopranoto (2003) believes that an information source very close for a farmer is another farmer who has successfully adopted a new technology or information obtained from a variety of sources. The successful farmer can function as an effective information source for other farmers. They can form close, friendly, similar views for handling a problem. Hadiyanto (2001) reports that rural livestock raisers tend to communicate among themselves on an interpersonal basis (five times a week) compared to an extension officer (once a week) whereas the urban ones seldom do so. The urban ones communicate more frequently with the extension officer on an interpersonal basis. The rural ones show close ties among themselves and the urban ones are generally independent.

Far Far (2009) finds that behavior of interpersonal communication is most frequently seen among groups of farmers. This is due to the fact that they share common values, beliefs, social status, and education. This is also found a study by Oktarina et al. (2009). They state that communicative activities among female farmers are high on interpersonal level whereas their group participation and use of mass media fall in the low scale.

\section{Communicative Behavior and Empowerment of Women Farmers}

Mardikanto (1993) behavioral change in the process of applying innovation that includes cognitive, psychomotor, affective dimensions can take place in a development communication process. This is what ADA officers usually do. An ADA officer communicates a message (in form of information) to influence one's cognitive dimension. When it is training, it influences his psychomotor dimension, whereas persuasion goes to his affection dimension. Change in the three dimensions causes his behavioral change. Therefore, this behavior change encourages his willingness to adopt innovation. Rogers (1983) argues that an agricultural development should be seen as a communication process where ADA officers provide useful information for farmers and help them to change their knowledge, attitudes and skills. To be effective, they should be helped to make use of information and technology imparted. In agribusiness management, one's competence to communicate widely with his surroundings interest to access information indicates his openness and innovative attitude. This attitude shows his independence. Openness to innovation or outside information by women farmers indicate their independence and enable them to add up new knowledge, attitudes, and skills; all these are useful for their decision making in managing their agricultural ventures (Haryani, 2004). When women farmers have access to agribusiness information system, to a variety of information sources-interpersonal communication, to ABA officers, mass media-then they are aware to increase their knowledge and have independence to make a decision. His study reports that vegetable growers in West Java interact more frequently therefore they gain new information to increase their vegetable crops. Agussabti (2002) supports this finding. Interaction among rural dwellers, families, and local leaders influence the dynamics of farmers in their agribusiness activity, awareness to their needs and independence on their decisions.

Tamba (2007) shows that farmers' competence in managing their vegetable business is still low. This is due to low awareness of the important role of information, competence to access sources of agricultural information, and less conducive to environment (physical/ infrastructure, social/ local leaders, families, availability of information, and extension officers). Moreover, the farmers seldom communicate among themselves, with other groups, ADA officers and innovators, and with public (not cosmopolite). In contrast with Lailogo's study (2003), the communicative behavior of female farmers is cosmopolite enough and participative in adopting innovation.

Farid (2008) argues that factors closely related to farmers' independence to make a decision in Bondowoso and 
Pasuruan Counties, East Java, among others are agricultural development activities, access to a variety of information sources, local leaders, agents and mass media. On the other hand, Marliati (2008) concludes that performance of ADA officers to help farmers falls in the low scale. In other words, it gives an impression of low the farmers' degree of independence. In addition, such condition is caused by ADA officers' low communicative competence, farmers' low learning capacity, less access to their formal education, lack of facilities provided by the local government and private sector, and less supportive values for improving the farmers' competence to manage their agribusiness enterprise.

Junaidi (2009) concludes that factors closely related to the vegetable growers' independence in making a decision are agricultural development activities, access to information, external influence, the growers' competence and capacity of agricultural human resources. This indicates that agricultural development can be a source of information that enables farmers to add up their knowledge and improve their skills. The higher access to information and communication with ADA officers, the more independent they make their decision.

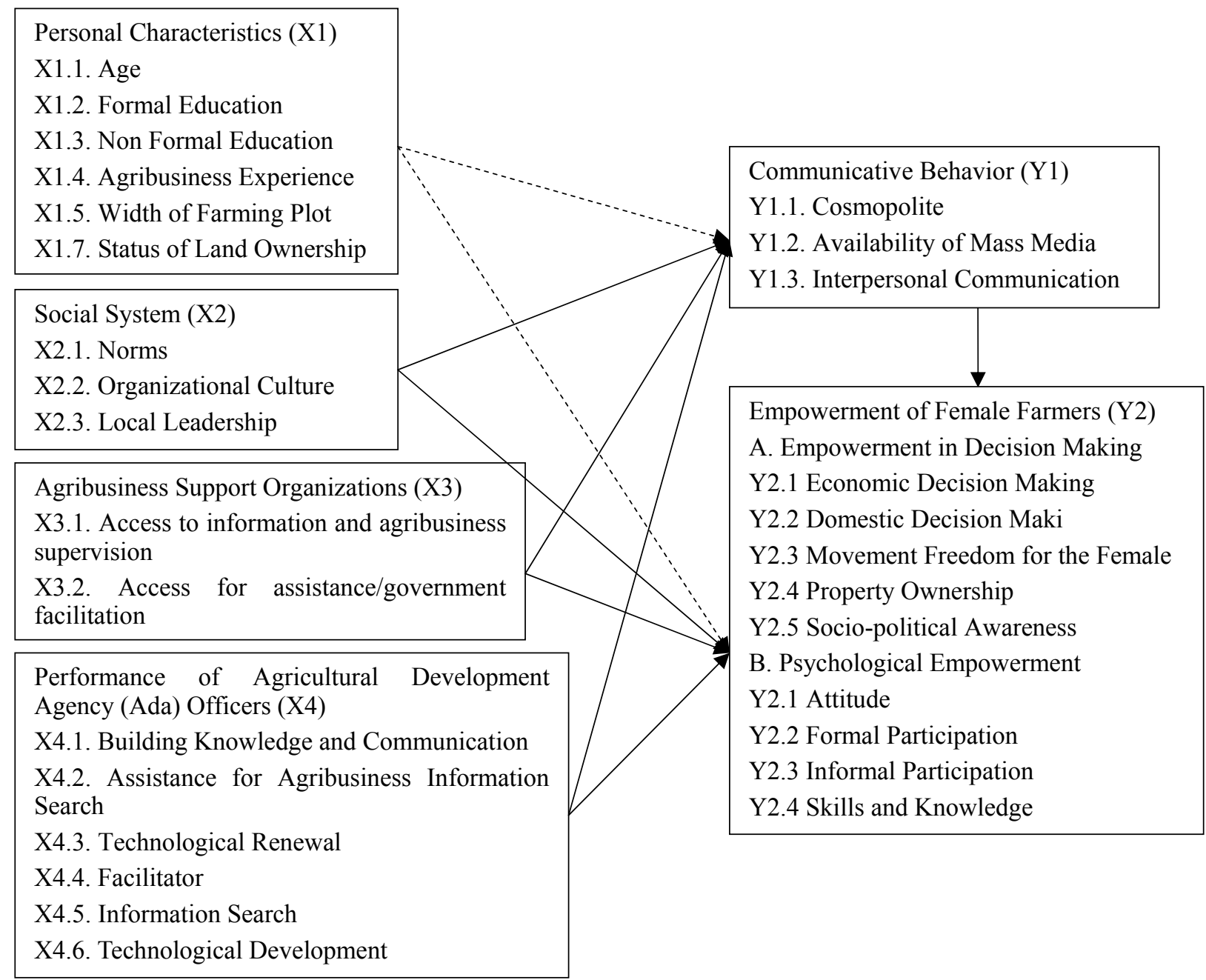

Figure 1. Communicative behavior and female farmer empowerment model

Female farmers need to have the same opportunity to increase their competence in all aspects, especially in agribusiness endeavor. Vitalaya (2000) states that the gender role is classified in three roles: reproductive (domestic), productive, and social. The arguments by Steinberg (2001), Sprinthal \& Collins (1995), Sumardjo (1999), Jarmie (1995), Florus (1995), Vitalaya (2000), Suparta (2001), World Bank (2002), Narayan (2003), Slamet (2003), and Sulistiyani (2005) state female farmer empowerment can be looked at their independent decision making and psychological empowerment (Zimmerman \& Perkins, 1995; Zimmerman, 1995, and Mosse (2007). Based on their theory and concepts, female farmer empowerment is seen through decision making and psychological empowerment. Their decision making competence is seen through the following dimensions: (1) competence to make an economic decision, (2) competence to make a domestic decision, (3) freedom to act, (4) 
asset ownership, (5) political awareness (Nessa, 2011). Psychological empowerment of a female farmer can be seen through the following dimensions: (1) attitude, (2) formal involvement, (3) non-formal involvement, and (4) skills and knowledge (Zimmerman, 1995).

Based on the previous studies of personal characteristics, social system, agribusiness support organizations, performance of ADA related to communicative behavior and empowerment, the following research design for this study is as follows.

The model for this research approach is depicted in the thought frame of independent and dependant variable relationship. The independent variables are personal characteristics of female farmers (X1), social system (X2), agribusiness support organizations (X3), and performance of agricultural development agency (ADA) (X4) whereas the dependent variables are communicative behavior of female farmers (Y1) female farmer empowerment in the trade system (Y2). This frame can be seen the Figure 1.

\section{Conclusion}

This paper discusses the role of social system, organization support, communication behavior (cosmopolitan, interpersonal communication, media) and extension agents, and proposed a conceptual framework for future study. Based on the explanation given, this paper therefore focuses on the aspects of communication behavior and empowerment of women farmers that are related to some variables which are the characteristics of women farmers, social system, the availability of supporting organizations for agricultural business and the performance of the empowerment of women farmers in agribusiness regarding their ability to make decisions and psychological empowerment in agricultural business.

\section{Acknowledgments}

The authors wish to thank the Universiti Utara Malaysia for funding this study under Insentive Grant for Postgraduate Study.

\section{References}

Abdurachman, D. H. (998). Hubungan profil petani peserta SLPHT dengan tingkat penerimaan informasi PHT berdasarkan wilayah di Kabupaten Sukabumi. Bogor: Pascasarjana IPB.

Agribisnis, B. (2003). Pengembangan agribisnis di Indonesia. Jakarta: Deptan, R.I.

Agussabti. (2002). Kemandirian petani dalam pengambilan keputusan adopsi inovasi (Kasus petani sayuran di Provinsi Jawa Barat). Bogor: Pascasarjarna IPB.

Anantanyu, S. (2009). Partisipasi petani dalam meningkatkan kapasitas kelembagaan kelompok petani (Kasus di Provinsi Jawa Tengah). Bogor: Sekolah Pascasarjana IPB.

Anwar. (2007). Manajemen pemberdayaan perempuan (Perubahan sosial melalui pembelajaran Vocational Skill pada keluarga nelayan). Bandung: Alfabeta.

Asngari, P. S. (2002). Pentingnya memahami penyuluhan pembangunan dalam rangka pemberdayaan masyarakat'dalam membentuk pola perilaku manusia pembangunan. Diedit Oleh: Adjat Sudrajad dan Ida Yustina. Bogor: IPB.

Bennis, W. G., Benne, K. B., \& Chin, R. (1969). The planning of change. New York: Holt-Rinehart and Winston, Inc.

Bernandin, H. J. D, \& Russell, J. E. A. (1993). Human resource management. McGraw-Hill, Inc, Singapore.

Bettinghaus, E. F. (1983). Persuasive communication. New York: Holt, Rinchart and Winston, Inc.

Chang, O. (2005). Buddhism and innovative organitional culture. Proceeding of the $11^{\text {th }}$ Asia Pacific Management Conference. Taiwan, 2A2-1 -2A2-4.

Daniel, M., Darmawati, \& Nieldalina. (2005). PRA: Participatory rural appraisal, pendekatan efektif mendukung penyuluhan partisipatif dalam upaya percepatan pembangunan pertanian. Jakarta: PT. Bumi Aksara.

Devito, J. A. (1989). The International Communication Book (5th ed.). New York: Harper and Row Publishers.

Far, R. A. (2009). Hubungan efektivitas komunikasi interpersonal dengan perilaku bercocok tanam padi sawah (Kasus Desa Waimital Kecamatan Kairatu Kabupaten Seram Bagian Barat). Bogor: Sekolah Pascasarjana IPB.

Farid, A. (2008). Kemandirian petani dalam pengambilan keputusan usahatani: Kasus petani sayuran di Kabupaten Bondowoso dan Kabupaten Pasuruan. Pascasarjana IPB, Bogor.

Florus, P. (1998). Pemberdayaan Masyarakat. Jakarta: IDRD. 
Gerbner, G. (1967). Mass media and human communication theor. In F. E. X. Dance (Ed.), Human communication theory. New York: Holt-Rinehart, \& Winston.

Gupta, V., Chandargi, D. M., \& Sundarswamy, B. (2004). Development of scale to measure the performance of extension personnel of different linkage activities scientists. Karnataka Journal Agriculture Sciences, 17(1), 63-67.

Hadiyanto. (2001). Perbandingan perilaku komunikasi peternak di desa urban dan desa rural. Media Pertanian Jurusan Sosek Industri Peternakan Fakultas Peternakan Bogor, 24(2), 12-18.

Hapsari, H. (2007). Perilaku komunikasi "sadar pangan dan gizi” pada akseptor KB Lestari (Kasus di Kecamatan Jatinangor, Kabupaten Sumedang). Jurnal Sosiohumaniora, 9(1), 24-36.

Hardjosoedarmo, S. (1996). Total quality management. Yogyakarta: C.V. Andi.

Haryani, M. (2004). Tingkat kemandirian wanita tani dalam pengelolaan usahatani sayuran (Kasus di Kecamatan Sukaraja Kabupaten Sukabumi Provinsi Jawa Barat) (Tesis). Bogor: Sekolah pascasarjana IPB.

Haryanto, B. (2009). Inovasi teknologi pakan ternak dalam sistem agribisnis tanaman ternak bahan limbah mendukung upaya peningkatan produksi daging. Jurnal Pengembangan Inovasi Pertanian, 2(3), 163-176.

Hayati. (2008). Perilaku komunikasi petani perempuan dalam difusi inovasi usahatani tanaman pangan di Desa Lingsar Kabupaten Lombok Barat. Makalah Seminar Nasional Alumni Fakultas Pertanian Universitas Mataram, 23-24 Februari 2008. PS Penyuluhan dan Komunikasi Pertanian FP-UNRAM, Mataram.

Herawati, T., Suwalan, S., Haryono, \& Wahyuni, S. (2000). Peranan wanita tani dalam usahatani keluarga di lahan rawa pasang surut. Proseding Nasional Lahan Rawa. Cipayung 25-27 Juli 2000. Pusat Penelitian dan Pengembangan Tanaman Pangan, Jakarta.

Hikmat, H. (2004). Strategi pemberdayaan masyarakat. Bandung: Humaniora.

Hoy, W. K., \& Miskel, C. G. (2001). Educational administration: Theory, research, and practice (6th ed.). Singapore: McGraw-Hill.

Ipriani. (2005). Partisipasi wanita tani pada usahatani padi sawah dan sumbangannya terhadap pendapatan keluarga di Desa Muara Emil Kecamatan Tanjung Agung, Kabupaten Muara Enim Provinsi Sumatera Selatan. Palembang: FP-UNSRI.

Jarmie, M. Y. (1994). Sistem penyuluhan pembangunan pertanian Indonesia (Disertasi). Bogor: Program Pasca Sarjana IPB.

Jokopusphito, S. (2006). Hubungan antara perilaku komunikasi dengan tingkat adopsi teknologi diversifikasi pangan dan gizi pada kelompok wanita tani di Kecamatan Pundong Kabupaten Bantul DIY-Yogyakarta (Tesis). Bogor: Sekolah Pascasarjana IPB.

Junaidi, Y. (2009). Studi komparatif pemberdayaan petani padi lebak dalam pengembangan sistem agribisnis antara lembaga pemerintah dan non pemerintah di Kabupaten Ogan Ilir (Tesis). Palembang: Pascasarjana UNSRI.

Kantor Kementerian Negara Pemberdayaan Perempuan R. I. (2007). Membangun Sinergi PUG Pemerintah dan Masyarakat. Makalah dalam Acara Pertemuan Regional 1 Pemberdayaan Lembaga Masyarakat (Wilayah Sumatera) di Pekan Baru, 7 Juni 2007. Kantor Meneg PP R.I, Jakarta.

Kantor Menteri Negara Pemberdayaan Perempuan R. I. (2000). Gender mainstreaming dalam program pembangunan. Jakarta: Kantor Meneg PP.

Kantor Menteri Negara Pemberdayaan Perempuan R. I. (2004). Keadilan dan kesetaraan perempuan dalam program pembangunan. Jakarta: Kantor Meneg PP.

Kantor Menteri Negara Peranan Wanita R. I. (1998). Peningkatan peranan wanita dalam pembangunan. Jakarta: Kantor Meneg Peranan Wanita.

Kantor Menteri Pemberdayaan Perempuan R. I. (2005). Pengarusutamaan Gender. Cetakan ke 4, 2005. Jakarta: Kantor Mneg PP.

Kaye, H. (1997). Mengambil keputusan penuh percaya diri. Jakarta: Mitra Utama.

Lailogo O. T. (2003). Hubungan perilaku komunikasi wanita tani dalam pengambilan keputusan inovasi penggemukan sapi poton. Tesis. Bogor: Pascasarjana IPB.

Laman, M. S., Avery, C. B., \& Frank, S. J. (1988). Young adult perception of their relationships with their Parents. Individual differences in connectedness, competence, and emotional autonomy. Journal Development Psychology, 24(5), 729-737. http://dx.doi.org/10.1037/0012-1649.24.5.729 
Laswell, H. D., \& Kaplan, A. (1969). "Power and society": A framework for political inquiry” dalam Pengantar Penyuluhan Pertanian. Surakarta: Hapsara.

Lionberger, H. F., \& Paul. H. G. (1982). Communications strategies: A guide for agriculture change agent. Danville, Illonis: The Interstate Printers and Publisher.

Lunenberg, F. C., \& Ornstein, A. O. (2000). Educational administration: Concepts and applications. Wadsworth, Belmont, CA.

Mannopo, C. N. (2009). Faktor-Faktor yang berhubungan dengan partisipasi wanita tani dalam usahatani kakao (Kasus di Kecamatan Palolo Kabupaten Donggala Provinsi Sulawesi Tengah) (Disertasi). Bogor: Program Pascasarjana IPB.

Mardikanto, T. (1993). Penyuluhan pembangunan pertanian. Surakarta: Sebelas Maret University Press.

Mardikanto, T. (2007). Penyuluhan pembangunan sebagai landasan penanggulangan kemiskinan bebasis potensi daerah. Pidato pengukuhan Guru Besar ilmu penyuluhan pertanian pada tanggal 10 Maret 2007. Surakarta: UNS Press.

Marliati. (2008). Pemberdayaan petani untuk pemenuhan kebutuhan pengembangan kapasitas dan kemandirian petani beagribisnis (Kasus di Kabupaten Kampar, Kabupaten Riau). Bogor: Pascasarjana IPB.

Mehra, R., \& Rojas, M. H. (2008). Women, food security and agriculture in a global market place. Washington, DC: International Center for Research on Women (ICRW).

Moser, C. (1989). Gender planning in third world: Meting practical and strategic gender needs. World Development, 17(11), 158-171. http://dx.doi.org/10.1016/0305-750X(89)90201-5

Mosse, J. C. (1996). Gender dan pembangunan. Terjemahan Half the World Half the Chance penerjemah Hartian SilawatiRika Anisa, Yogyakarta.

Muliady, T. R. (2009). Faktor-faktor yang mempengaruhi kinerja penyuluh pertanian dan dampaknya pada perilaku petani di Jawa Barat (Disertasi). Bogor: Pogram Pascasarjana IPB.

Mulyana, B. S., \& Surono, S. (2010). Pembangunan perdesaan: Meningkatkan kesejahteraan masyarakat perdesaan dalam pembangunan perdesaan dalam Rangka Peningkatan Kesejahteraan Masyarakat. Bogor: IPB Press.

Mulyana, D. (2007). Komunikasi suatu pengantar. Bandung: Remaja Rosdakarya.

Munaf, D. R. (2004). Digital divide and cultural diversity in Indonesia: Information policy. Proceeding of International Congres of Information: Information, knowledge and society challenges of new era. April, Havana.

Mustaffa, C. S. (1998). Budaya organisasi: Kepentingannya dalam konteks pengurusan kerajaan tempatan. Seminar Kebangsaan kerajaan Tempatan. INTAN, Bukit Kiara: Sekolah Pembangunan Sosial, Universiti Utara Malaysia dengan kerjasama INTAN, 24-25 November.

Narayan, D. (2002). Empowerment and poverty Reduction: A Sourcebook. Washington, DC: World Bank

Nessa, T. (2011). The impact of microfinance institutions on women empowerment in Rajshahi (Disertation). Kedah, Sintok: Universiti Utara Malaysia

Nuryanto, G. B. (2000). Kompetensi penyuluh dalam pembangunan pertanian di Provinsi Jawa Barat (Disertasi). Bogor: Program Pascasarjana IPB.

Nuryanto, G. B. (2008). Kompetensi penyuluh dalam pembangunan pertanian di Provinsi Jawa Barat. Bogor: Sekolah Pascasarjana IPB.

Oktarina, S., Hamzah, M., \& Junaidi, Y. (2009). Peran komunikasi dalam pemberdayaan kelompok wanita tani pada usahatani padi pada daerah transmigrasi Provinsi Sumatera Selatan. Indralaya: Lembaga Penelitian UNSRI.

Pambudy, R. (1999). Perilaku komunikasi, perilaku wirausaha peternak, dan penyuluhan dalam sistem agribisnis peternak ayam (Disertasi). Bogor: Sekolah Pasca Sarjana. IPB.

Perkins, D. D., \& Zimmerman, M. A. (1995). Empowerment theory, research, and appilication. American Journal of Community Psychology, 23(5), 569-579. http://dx.doi.org/10.1007/BF02506982

Pertiwi, P. R. (2009). Persepsi dan pemilihan petani terhadap saluran komunikasi penyuluhan mengenai informasi pengelolaan usahatani padi (Kasus petani Kabupaten Serang) (Tesis). Bogor: Pascasarjana IPB Bogor.

Pical, V. J. (1997). Tahapan adopsi teknologi pengolahan ikan oleh wanita pedesaan (kasus di Kabupaten 
Maluku Tengah). Bogor: Program Pasca Sarjana IPB.

Quisumbing, A. R., \& Lauren, P. (2009). Promising approaches to address the needs of poor female farmers: Resources, constraints, and interventions. World Development Journal, 20(10), 1-12.

Raecside, R., \& Walker, J. (2001). Knowledge: The key to organizational survival. The TQM Magazine, 13(3), 156-160. http://dx.doi.org/10.1108/09544780110366105

Rahman, M., Hammadur, \& Naoroze, K. (2007). Women empowerment through in aquaculture: Experience of a large-scale technology demonstration project in Bangdalesh. Journal of Sociological Science, 3(4), 161-17.

Rakhmat, J. (2005). Psikologi komunikasi. Cetakan 1. Bandung: Remaja Rosdakarya.

Rakhmat, J. (2008). Psikologi komunikasi. Cetakan 2. Bandung: Remaja Rosdakarya.

Rogers, M. E. (1983). Diffusion of Innovation. New York: The Free Press; A Division of MacMillan Publishing Co, Inc.

Rogers, M. E. (1995). Diffusion of innovations (4th ed.). New York: The Free Press.

Rogers, M. E., \& Shoemaker, F. F. (1971). Communication of innovations (2nd ed.). New York: The Free Press. A Division of Mac-Milland Publishing Co.Inc.

Saleh, A. (2006). Tingkat penggunaan media massa dan peran komunikasi anggota kelompok peternak dalam jaringan omunikasi penyuluhan. Bogor: Pascasarjana IPB.

Salkind, N. J. (1985). Theories of human development. New York: John Willey and Sons, New York.

Sampson, J. P., Jr., Peterson, G. W., Lenz, J. C., \& Reardon, R. C. (1992). The career development quarterly. National Career Developmen Association.

Saragih, B. (2000). Sektor agribisnis jalan keluar krisis dan menuju kejayaan ekonomi nasional. Artikel Sinar tani, 6-12 Spetember 2000, No. 2858 Tahun XXXI.

Saragih, B. (2001). Agribisnis paradigma baru pembangunan ekonomi berbasis pertanian. Bogor: Pustaka Wirausaha Muda.

Sayogyo, P. (1985). Peranan wanita tani dalam perkembangan masyarakat desa. Jkarta: C.V. Rajawali.

Schrool, J. W. (1980). Modernisasi. Penerjemah: R. G. Soekadijo. Gramedia, Jakarta.

Shardlow, S. (1998). Value, ethics and social work. In A. Robert., L. Dominelli, \& M. Payne (Eds.), Social work: Themes, issues and critical debates (pp. 23-33). London: Macmillan Press Ltd.

Sidu, D. (2006). Pemberdayaan masyarakat sekitar kawasan hutan lindung jompi Kabupaten Muna, Sulawesi Tenggara. Bogor: Sekolah Pascasarjana IPB.

Slamet, M. (1992). Perspektif ilmu penyuluhan pembangunan menyongsong era tinggal landas' dalam penyuluhan pembangunan di Indonesia: Menyongsong abad XXI. Diedit oleh A.Vitalaya, S., Tjitropranoto, P, dan Wahyudi, R. Jakarta: PT. Pustaka Swadaya Nusantara.

Slamet, M. (2003). Memantapkan penyuluhan pertanian di Indonesia. Membentuk pola perilaku manusia pebangunan. Diedit: Ajad Sudradjat dan Ida Yustina. Bogor: IPB Press.

Soekanto, S. (2006). Sosiologi: Suatu pengantar. Jakarta: Raja Grafindo Persada.

Sprinthaal, \& Collins. (1995). Adolescent psychology. New York: McGraw Hill. Inc.

Suliastiyani, A. T. (2004). Kemitraan dan model-model pemberdayaan. Gaya Media, Yogyakarta.

Sumardjo. (1999). Transformasi model penyuluhan pertanian menuju pengembangan kemandirian petani (Kasus di Provisni Jawa Barat) (Disertasi). Bogor: Program Pascasarjana IPB.

Suparta, N. (2001). Perilaku agribisnis dan kebutuhan penyuluhan peternak ayam ras pedaging (Disertasi). Bogor: Program Pascasarjana IPB.

Syamsuri, S. A. (2010). Membangun ekonomi desa melalui pengembangan (revitalisasi) koperasi unit desa dalam pembangunan perdesaan dalam rangka peningkatan kesejahteraan masyarakat. Bogor: IPB Press.

Tamba, M. (2007). Kebutuhan informasi pertanian dan aksesnya bagi petani sayuran: Pengembangan model penyediaan informasi pertanian dalam pembemberdayaan petani, kasus di Provinsi Jawa Barat. Bogor: Sekolah Pascasarjana IPB.

Tarmali. (1994). Partisipasi petani dalam penyuluhan dan penerapan program supra insus. Studi kasus di WKPP Glumpang Tiga, Kabupaten Pidie, Daerah Istimewa Aceh (Tesis). Bogor: Program Pascasarjana IPB.

Tubbs, S. L., \& Moss, S. (2000). In D. Mulyana (Ed.), Human communication: Konteks-konteks komunikasi. 
Bandung: Remaja Rosdakarya.

Van Den Ban, A. W., \& Hawkins, H. S. (1999). Penyuluhan pertanian. Terjemahan: A. D. Herdiasti. Yogyakarta: Kanisius.

Vitalaya, A. P. (2000). Masalah gender. Makalah pada Lokakarya EXPERT dan UMA-BUILD (Urban Management Advisor-Breakthrough Urban Urban Initiatives for Local Development). Cikini, 28-30 Juli 2000. Jakarta: UNDP/UCHS.

Wahyuni, S. (2003). Kinerja kelompok tani dalam sistem usahatani dan metode pemberdayaannya. Jurnal Balitbang Pertanian, 22(21).

Wardhani, A. (1994). Hubungan karakteristik demografis dan motivasi kognitif peternak dengan penggunaan sumber-sumber informasi tentang ayam buras di Desa Cisontol, Kabupaten Ciamis (Tesis). Bogor: Program Pascasarjana IPB.

Wariso, R. A. M. (1990). Memberdayakan kelompok wanita tani (KWT) untuk mempercepat proses adopsi difusi teknologi sistem usahatani. Prosiding Lokakarya Regional pada tanggal 1-2 Maret 1999. Kerjasama Kantor Wilayah Deptan Propinsi NTT dan BPTP Naibonat, NTT-Departement of primary Industry and Fisheries, Darwi,

Wiryanta, A. (2009). Hubungan pendedahan media massa, komunikasi interpersonal dan sikap dengan perilaku penjimatan tenaga elekterik di Kota Depok Indonesia (Disertasi Ijazah Doktor Falsafah). Kedah, Sintok: Universiti Utara malaysia.

Wiryanta. (2009). Hubungan pendedahan media massa, komunikasi interpersonal dan sikap dengan perilaku penjimatan tenaga elekterik di Kota Depok Indonesia (Disertasi Ijazah Doktor Falsafah). Kedah, Sintok: Universiti Utara malaysia.

Women in Patriarchal Societies. (2011). Women in patriarchal. Journal Gender and Societies. Jakarta: Badan Penelitian dan Pengembangan Deptan.

Wood, Y. T. (1997). Communication theories in action: An introduction. New York: Wadsworth Publishing Company.

World Bank. (2007). World development report 2008. Agriculture for development. Washington DC: World Bank.

Wulansari, W. (2003). Kajian gender dalam pengelolaan sumberdaya pesisir dan laut di Pulau Untung Jawa (Disertasi). Bogor: Program Pascasarjana IPB.

Zapar, S., Batool, Z., \& Bano, S. (2005). Female participation in decision making process in family matters in District Faisalabad-Pakistan. Journal of Agriculture \& Social Sciences, 1(3), 285-287.

Zimmerman, M. A. (1995). Psychological empowerment: Issues and illustration. American Journal of Community Psychology, University of Michigan, 23(50), 581-589. http://dx.doi.org/10.1007/BF02506983

\section{Copyrights}

Copyright for this article is retained by the author(s), with first publication rights granted to the journal.

This is an open-access article distributed under the terms and conditions of the Creative Commons Attribution license (http://creativecommons.org/licenses/by/3.0/). 